\section{IJIKMMENA}

3,1

1

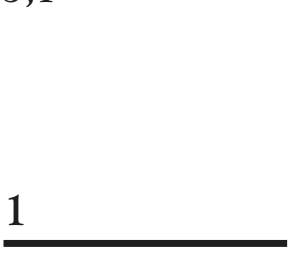

\title{
HOST COUNTRY FACTORS AND INWARD FDI-INDUCED TECHNOLOGY TRANSFER: THE CASE OF THE UAE
}

\author{
Fahad Saif Harhara' \\ Brunel University, UK \\ Amer Al Roubaie ${ }^{2}$ \\ Al Ahlia University, Kingdom of Bahrain \\ Wafi Al Karagouli ${ }^{3}$ \\ Brunel University, UK
}

\begin{abstract}
Purpose: The purpose of this study was to investigate the host country factors that impact the transfer of technology arising from Foreign Direct Investment for a resource-rich nation such as the United Arab Emirates.

Design/methodology/approach: Consistent with prior literature, a labour productivity model that isolates the effects of increased capital intensity has been developed to proxy for the presence of technology transfer. Using an OLS model, the dependent variables were the stock of FDI, imitation, labour mobility, trade openness, absorption capacity, economic development, competition and institutional development. The model was estimated using data for the period 1980 to 2010 .
\end{abstract}

${ }^{1}$ Fahad Saif Harhara, Brunel Business School, Brunel University, Kingston Lane, Uxbridge, Middlesex UB8 3PH, UK, Email: fahadsaif@aol.com. And: P. O. Box International Journal of Innovation and 25242, Abu Dhabi, UAE

${ }^{2}$ Dr Amer Al Roubaie, Al Ahlia Business School, Al Ahlia University, P. O. BOX 10878, Manama, KINGDOM OF BAHRAIN, Email: aalroubaie@ahlia.edu.bh ${ }^{3}$ Dr Wafi Al Karagouli, Eastern Gateway Building, Brunel Business School, Brunel University, Kingston Lane, Uxbridge, Middlesex UB8 3PH, UK, Email: Wafi.Al- 
Findings: The study found that the level of economic development positively impacts on labour productivity, which is consistent with prior research. There is also evidence to show that absorptive capacity has a positive impact on the level and speed of technology transfer from the MNEs to domestic firms. The level of competition due to the presence of MNEs encourages domestic firms to reassess their production processes and innovate in order to remain competitive. The study found a negative impact for trade openness, contrary to prior studies showing that this is due to the importance of the re-export sector in the economy.

Originality/value: The key value of this study is its identification of the important host country factors that can lead to technology transfer for a small resource-rich country that is the third largest re-export centre and the main beneficiary of non-hydrocarbon-based inward investment in the Gulf region.

Keywords: Foreign Direct Investment, Technology Transfer, Host Country Factors, Knowledge Transfer, Absorptive Capacity, United Arab Emirates

Paper type: Empirical investigation

\section{INTRODUCTION}

The research interest in Foreign Direct Investment (FDI) has increased greatly in recent years due to the change of perspectives among global policy makers. Traditionally, policy makers, especially those from developing countries, were hostile towards FDI, viewing it as parasitic and hindering the development of domestic industries, especially those focused on export. Today, policy makers are more encouraging and seek to aggressively attract FDI to their countries. The change of view is due to the positive effects of FDI, such as productivity gains, technology transfer to host nation firms, the introduction of new processes, managerial skills and know-how in the domestic market, employee training, international production networks, and access to markets. However, the most important is transfer of technology, contributing to growth in larger measure than domestic investment. Prior literature shows that FDI increases the rate of technical progress in the host country through a contagion effect from the more advanced technology, management practices, etc., used by foreign firms. On the basis of these assertions governments have often provided special incentives to foreign firms to set up companies in their countries (Carcovic and Levine, 2002). 
IJIKMMENA 3,1

The empirical evidence of the benefits of FDI, both at the firm level and national level, remains ambiguous. De Gregorio (2003) found that FDI allows a country to introduce technologies and knowledge that are not readily available to domestic investors, and in this way increases productivity growth throughout the economy. FDI may also bring in expertise that the country does not possess, and foreign investors may have access to global markets, hence bringing in cheaper finance. De Gregorio (2003) found that increasing aggregate investment by $1 \%$ increased the economic growth of Latin American countries by $0.1 \%$ to $0.2 \%$ a year. However, when FDI was increased by the same amount, the growth in GDP was approximately $0.6 \%$ a year during the period 1950-1985. This indicates that FDI is three times more efficient than domestic investment.

In order to attract FDI, governments have created a more liberalized regulatory system as well as direct market interventions. However, it is almost impossible to determine the extent of the direct intervention because more often than not they are confidential as well as being very complex agreements that seek to hide the true cost to the government. Despite their secretive nature, certain examples are in the public domain and highlight the scale and extent of the activity. Head (1998) found that the state government of Alabama in the USA paid US $\$ 230$ million or the equivalent of US $\$ 150,000$ per employee to Mercedes Benz to locate their plant in the state in 1994. Girma et al. (2001) reported that the UK government paid Samsung the equivalent of US $\$ 30,000$ per employee while Siemens was paid US $\$ 50,000$ per employee to locate in the economical deprived area of northeast England. Other governments, including Ireland, offer a blanket incentive in the form of a taxation rate of only $10 \%$ for all inward manufacturing investment.

The inducements paid to inward investment have intensified the competition between governments. In a recent example, the US semi-conductor manufacturer Intel chose to establish the largest semiconductor plant in Vietnam rather than Dubai because the former provided far greater inducements compared to the latter. The obvious question that arises is why do governments participate in these bidding wars in order to attract inward investment? Proponents of such inducements argue that they are justifiable as long as the total benefit is greater than the cost. Inward FDI is argued to improve the productivity of domestic firms through technology transfer. Proponents of this view claim that new knowledge into the host country is a public good and 
hence this spillover effect has a positive impact on the economy. If such an argument is in fact true then one can claim that foreign firms do make a positive contribution to the host economy. Despite that large volume of empirical work that has been carried out examining the positive spillover effects from FDI there appears to be little in the way of a conclusive result. The prior literature has found very mixed results even as far as the same inward investment is concerned.
Host country factors and technology transfer in

UAE

\section{LITERATURE REVIEW}

A review of the literature to date has identified four main indirect channels of technology transfer from the MNE to the domestic firms, namely: imitation; human capital and exports. Some studies, such as Görg and Greenaway (2001) argue that competition is also a fourth channel by which technology transfer can take place. However, we feel that any overseas competition itself is not a channel but a situation to which domestic firms need to react to maintain their market position.

The usual manner in which domestic firms react to overseas competition is to imitate their technology so as to be on a par with them (Mansfield and Romeo, 1980). The extent to which host country firms can imitate foreign MNEs largely depends on the complexity of the product, process, management or organisational innovation (Das, 1987; Wang and Blomström, 1992). The simpler and to some extent the cheaper a particular innovation is to imitate, the greater the likelihood of it being adopted by the host country's firms. Of course, with near global membership of intergovernmental organisations such as the World Intellectual Property Organisation (WIPO), it is not possible for host country firms to simply replicate the foreign products or processes. However, the fact that the host country firms can see the demonstrable benefits of the innovation means that they are more likely to adopt it (Findlay,1978; Sinani and Meyer, 2004). At the same time the increased level of competition stimulates a faster rate of technological adoption. To a certain extent this argument is supported by studies such as that of Mansfield and Romeo (1980), which found that for a sample of UK firms, their adoption of technology was hastened in response to technology transfers from US MNEs.

The first hypothesis which we label as $\mathrm{H} 1$ seeks to identify the relationship between FDI and the value of the investment. This is the core variable of the hypotheses 
IJIKMMENA 3,1

It is not only the fear of competition that can result in imitation but also the process of "seeing and doing", i.e. the demonstration effect. Blomström and Kokko (1998) reported that the regular interactions between foreign and host country firms leads to a natural flow of information. The presence of a MNE makes the host country firms more aware of the current innovations. Over time these interactions give comfort to the host country and imitation takes place. Sinani and Meyer (2004) argued that imitation can take through labour turnover, whereby as employees move from the MNE to the host country firm they take with them tacit knowledge. Similarly, the study argues that in some cases employees establish their own firms and in the process take the tacit knowledge with them.

H2: The ability to imitate inward FDI has a positive impact on the level of technology transfer to host country firms.

\section{HUMAN CAPITAL}

The importance of labour in traditional economic models is well established with the work of Cobb and Douglas (1928), Solow (1956) and Swan (1956). The interesting contribution of the latter model is that it's not just the size of the population that is important but its productivity. In this context inward FDI becomes extremely important for host country nations as it is an effective manner by which they can increase labour productivity. In this respect Noorbakhsh et al. (2001) point out that "FDI is not only a source of finance and employment. For developing country governments, FDI can also be a medium for acquiring skills, technology, organizational and managerial practices and access to markets". However, the relationship between inward FDI and labour productivity is not so clear cut. Enderwick (1985) reported that there is considerable disagreement in the literature as to whether the presence of a MNE in the host country has a positive impact on labour productivity. Enderwick (1985) argued that the exact impact of a MNE on labour productivity is the end result of various factors, some of which are in its control while others are not. Examples of the former include the quantity of capital and labour to be used in the host country, division of MNE country and host country employees and the type of technology that is brought into the country. Factors which are outside the control of the MNE tend to be the economic, social and labour market aspects, such as use of fiscal policy, labour union power and strength, work ethic and so on. 
The sheer nature of a MNE and its need to supply a consistent product or service implies that they add to the skills in the host country through training and educational programmes (UNCTAD, 2001). However, UNCTAD (2001) found that even though MNEs may carry out training programmes they tend to find that the knowledge base required is usually in short supply. Despite the supply constraints, MNEs do provide training to people who would not have received it in the absence of the foreign presence (Enderwick, 1985). The same study also argued that such training programmes may also stimulate the interest of employees to invest in their own education to take advantage of the opportunities available within and outside the MNE. UNCTAD (1999) found that although training was provided by MNEs it tended to be operational in nature, seeking to increase the productivity of employees. More importantly, UNCTAD (1999) found that the training was aligned to the technology, which was linked to host country education and skill base. Therefore, in host countries where the education was low, the training provided was minimal. As such it was found that the MNEs did not invest in a more sophisticated and long term skills upgrade, which is required to carry out advanced level of tasks. To the advantage of host country employees, the pace of change of technology has resulted in more frequent and rapid training but nevertheless it is not on a par with the MNE country level.

O'Connor and Lunati (1999) argued that low educational levels in the host country increase the MNE's training cost and hinder the introduction of more sophisticated technology. The authors point out that "improvements in productivity require not only adequate investment in worker training but also financial incentives linked to enhanced job responsibility and performance". More recent studies in this area have tended to focus on FDI in the enlarged European Union. Typical of such studies is Casado (2000), which found MNEs to have made substantial investments in upgrading the host country skill level as a result of poor educational systems and the inability of these workers to compete globally. The study found that the level of training provided was not limited to the assembly or low level worker but throughout the organisational structure up to the managing directors. The training ensured that the MNE was able to have the required skills set. Based on the above discussion, we can derive the following hypothesis which we empirically test in this study:

H3: The host country's level of human capital has a positive impact on the level of technology transfer by host country firms.
Host country factors and technology transfer in UAE 


\section{TRADE OPENNESS}

\section{3,1}

Firms who are exposed to the international market are more likely to benefit from what is termed the trade based technology transfer from FDI (Aitken, Hanson and Harrison, 1997; Barrios, Görg and Strobl, 2003; Greenaway, Sousa and Wakelin, 2004). Prior literature has identified three main channels by which trade technology transfer may take place from FDI to the domestic firm. In the first instance, MNEs are assumed to have better access regarding foreign markets. Once a domestic firm has started exporting regularly, it builds up a repository of information of what works in a particular market and what does not. MNEs tend to capitalize on this experience by increasing the number of target markets. In doing so the domestic firm also learns from the MNE and a form of imitation tends to take place. Using a sample of Mexican firms, Aitken et al. (1997) also found that the probability of domestic firms beginning or increasing the number of countries they export to increases with the presence of MNEs.

Second, the aspect of imitation can also be relevant for export technology transfer whereby the domestic firm acquires the production and management techniques from the MNEs. Once these techniques have been acquired the domestic firm will tend to capitalize on them through an increase in exports. In the process of exporting, the domestic firms are also exposed to other techniques which may be superior to the initial MNE, and these too are also imitated. As a result, the domestic MNE initiates the technology transfer process and the foreign firms extend it. In many senses the extension of technology by the domestic firm may be due to the third channel, which is that both the domestic firm and the MNE compete in the home market. As a result, the domestic firm needs to extend its market and hence enters the area of exports where the competition increases between the two firms. Consequently, the domestic firm seeks to gain a competitive advantage by acquiring superior capabilities. Greenaway et al. (2004) examined both of these export technology transfer channels and found that the presence of a MNE certainly increases the probability of the domestic firm to export. However, the study found no impact of the MNE on the domestic firms' export ratio. There is however no consensus in prior literature regarding the presence of a MNE on the export probability of the domestic firm. Bhagwati (1994), de Mello (1997), Barrios and et al. (2003) and Yao (2006) amongst others argued that the trade regime is an important factor in the level of export technology transfer from FDI. Based on 
the above discussion we can derive the following hypothesis, which we empirically test in this study:

H4: The more open a trade regime in the host country the more likely it is to experience technology transfer to its firms from inward FDI.
Host country factors and technology transfer in

$\mathrm{UAE}$

\section{ABSORPTIVE CAPACITY}

For a firm to make effective use of new technology it needs to have a certain level of prior knowledge and thus derive a business benefit. This idea was first formalised by Cohen and Levinthal $(1989,1990,1994)$ to explain the firm's level prior knowledge and capabilities that need to be present in order for it to effectively innovate. Cohen and Levinthal (1990) define absorptive capacity as the ability "to recognize the value of new, external knowledge, assimilate it, and apply it to commercial ends". The basis of this study is that innovation is the result of prior knowledge and the divergence of new technology from what the firm already knows. In other words, if the new information is closely related to what the firm already knows, then the likelihood of adoption is greater, as is the speed. Similarly, if the new information is significantly different then the likelihood and speed of adoption is lower (Lane and Lubatkin 1998).

The Cohen and Levinthal (1990) study tended to place a high level of importance on prior research and development $(R \& D)$ as a basis of absorptive capacity. However, this narrow focus may be limited and in order to fully recognize and assimilate new information a firm may need to have organisational absorptive capacity. This narrow definition led Zahara and George (2002) to examine additional areas of absorptive capacity, as a result of which they identified two types, namely: potential absorptive capacity and realized absorptive capacity. Through these two groupings of absorptive capacity, Zahara and George (2002) extend the earlier definition to state it as "a set of organizational routines and processes by which firms acquire, assimilate, transforms and exploit knowledge to produce a dynamic organizational capability". According to Zahara and George (2002) the potential absorptive capacity is further divided into two aspects, which are the ability to correctly identify and acquire the externally generated knowledge. Second, the firm needs to have appropriate policies and processes in order to make use of the new knowledge. In essence, Zahara and George (2002) refer to potential absorptive capacity which "makes the firm receptive to acquiring and 
IJIKMMENA 3,1

9 assimilating external knowledge". Similarly, realized absorptive capacity is also divided into two components, whereby the first looks at "a firm's capability to develop and refine the routines that facilitate combining existing knowledge and the newly acquired and assimilated knowledge". The second component examines the ability of the firm to derive a financial return from its new knowledge. Based on the above discussion we can derive the following hypothesis:

H5: The greater the absorption capacity of the host country firms, the more likely it is to experience technology transfer to its firms.

\section{LEVEL OF ECONOMIC DEVELOPMENT}

One area where the host country makes a considerable impact to the extent of technology transfer of inward FDI is its current level of economic development (Blomström and Kokko, 1998). Economic development is a multi-dimensional concept which implies an improvement in income, social and institutional factors. North (1990) argues that of these three aspects of economic development, the level of income is the most directly measured. This in itself is the outcome of the development process generated through social factors and facilitated by the country's institutions. Therefore, by measuring the income, one is essentially measuring the efficiency and effectiveness of the other two aspects of economic development.

Blomström and Kokko (1998) examined the impact of host country economic development and technology transfer using a cross country study. The results of this study showed that inward FDI had a positive impact in the higher income developing countries and not in the lower incomes group. Borensztein et al. (1998) in a more extensive study, examined 69 developing countries during the 19 year period from 1970 to 1989. The study found a weak relationship between inward FDI and economic growth. However, when the researchers included a proxy measure for economic development (i.e. level of education of the labour force) there was a statistically significant and positive impact on growth. These results lead Borensztein et al. (1998) to conclude that the level of the host country's economic development has a positive impact on the effectiveness of inward technology transfer. These results were confirmed by de Mello (1999), Campos and Kinoshita (2002), and Tu and Tan (2012). Based on the above discussion we can derive the following hypothesis: 
H6: The greater the level of economic development in the host country the more likely it is to experience technology transfer to its firms from inward FDI.

\section{COMPETITION AND CROWDING OUT}

Wang and Blomström (1992) and more recently Glass and Saggi (2002) took a different approach from traditional economics as far as the presence of MNE into the domestic market is concerned. Both of these studies argued that the entry of a MNE into the domestic market increases competition, which induces the host country firms to reassess their market position. As a result, the host country firms reassess their existing production processes (i.e. current technological base) and seek out more efficient production methods (i.e. new technology). This adoption of new technology comes about from the realization that if the domestic country firms do not effectively compete with the MNEs they will be driven out of the market. In the process the consumers benefit, as both domestic country firms and MNEs provide a product made using modern technology, which tends to be of a superior quality and lower price.

Aghion and Howitt (1998) found that competition from MNEs can induce domestic firms to innovate and hence acquire modern technology in three different ways. First, technology is required for the survival of the domestic firm in the absence of which it could face bankruptcy. Aghion and Howitt (1998) refer to this as the "Darwinian Effect". Second, if the MNE and the domestic firms have similar products or production processes, then according to Aghion and Howitt (1999), the former will seek to acquire modern technology in order to increase their lead over the latter. Aghion and Howitt (1999) refer to this as "Neck and Neck competition": strong rivalry between domestic firms and the MNE leads to technology transfer through acquisition or even internal development. Third, skilled workers seek to derive a higher return and hence move from older production lines to newer ones. As a result, the competition for skilled workers induces firms to acquire new technology. Aghion and Howitt (1999) refer to this as the "Mobility Effect". Nickell (1996), Nickell et al. (1997), Grosfeld and Tressel (2001) and Disney et al. (2003) used different proxies to find the importance of economic development on technology transfer from FDI. Based on the above discussion we can derive the following hypothesis:

H7: A greater level of competition from inward FDI leads to a higher level of technology transfer to host country firms.
Host country factors and technology transfer in UAE 
Prior literature has found that MNEs can play an important role in the development of institutional structures that support the efficient functioning of a market economy. Anderson et al. (1996) found that the presence of MNEs in transition economies greatly reduces the fragility of the financial sector. At the same time governments are eager to attract new inward FDI, especially from large MNEs with financial inducements and change in the regulatory structures, as discussed earlier in this study. McMillan (1993) argues that MNEs in some cases not only lobby for the change in the regulatory structure, but through their close working relationship with the governments concerned are able to influence the interpretation and application of new regulation.

There are two reasons why a MNE may wish to lobby for institutional change that leads to an improvement in the host country. First, Dowell et al. (2000) argued that MNEs produce at global levels so that they can benefit from the same production process and product designs regardless of the country in which the goods are assembled or manufactured. As a result MNEs do not want any particular country to impose ad hoc changes or different regulation. Therefore, MNEs seek to adopt the highest global standards and systems and then lobby each country to do the same. As a result, they have a positive impact on the host country. From a technology transfer viewpoint, the improvement in the institutional structure implies that host country firms are required to adopt the higher standards, which may require an improvement in their fixed investments. Second, MNEs serve the global market and hence any deviation or reduction in standards may be viewed by customers as an act of unethical behaviour. To a large extent the fact that MNEs have international linkages goes a long way to allow them to adopt self-regulatory standards (Zarsky 1999). As MNEs adopt a self-regulatory environment, so do the host country firms, and hence knowledge is transferred from the former to the latter. Based on the above discussion we can derive the following hypothesis:

H8: The more open the host country the more likely it is to experience technology transfer to host country firms.

In Table 1 we summarise our hypotheses, which we test in this study along with our expected outcomes based on prior research. 
Type of effect

Hypothesis Variable Expected direction or Sign

Core variable

FDI Stock

Technology transfer channels

Imitation

Human Capital

Trade Openness

Host country factors

Absorptive Capacity

Economic Development

Competition and Crowding Out

Institutional Development
H1

FDIS-

TOCK

H2 IMITATE

H3 LABOUR

H4 OPEN

H5

H6

$\mathrm{H} 7$

$\mathrm{H} 8$

ABSORP
ECDEV

COMPETE

INSTIDEV
Host country factors and technology transfer in

UAE

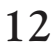

Note: the definitions and sources of data are provided in section 7.4

\section{DATA AND METHODOLOGY}

In accordance with studies such as Kokko (1994), Gorg and Strobl (2002), Barrios et al. (2004), and Ruane and Ugur (2005), we estimate a model whereby labour productivity is the dependent variable. In doing so we explicitly assume that the presence of MNEs impacts the domestic output per employee. A labour productivity measure as opposed to combined labour and capital total factor productivity has the key advantage that it isolates the effects of increased capital intensity on labour productivity. More importantly, a labour productivity model is consistent with the development of our hypothesis, whereby we argue that the presence of MNEs leads to a transfer of technology through various channels and in doing so raises their productivity (Waltz, 1997).

The model of production function that is estimated in this study is as follows:

$\mathrm{LP}=\mathrm{f}$ (Stock of FDI, technology transfer channels, Host country factors)

Equation 1

where LP refers to the level of labour productivity. The technology transfer channels and host country factors are those as listed in Table 1 and described below. 
IJIKMMENA

3,1

As a result of our hypotheses equation 1 can be written as:

$$
\begin{array}{r}
\text { LP }=\alpha+\beta_{1,1} \text { FDISTOCK }+\beta_{2,1} \text { IMITATE }+\beta_{3,1} \text { LABOUR }+\beta_{4,1} \text { OPEN } \\
+\beta_{5,1} \text { ABSORP }+\beta_{6,1} \text { ECDEV }+\beta_{7,1} \text { COMPETE }+\beta_{8,1} \text { INSTIDEV }+\varepsilon \\
\text { Equation 2 }
\end{array}
$$

This implies that labour productivity is dependent on the stock of FDI, imitation, labour mobility, trade openness, absorption capacity, economic development, competition and institutional development. In this equation we isolate the impact of technology transfer only to domestic firms through the subscript 'l', which implies local. However, the actual model that we estimate in this study is shown in equation 3 below.

$$
\mathrm{LP}=\alpha+\beta_{1} \text { FDISTOCK }+\beta_{2} \text { IMITATE }+\beta_{3} \text { LABOUR }+\beta_{4} \text { OPEN }+\beta_{5}
$$
$\mathrm{ABSORP}+\beta_{6} \mathrm{ECDEV}+\beta_{7}$ COMPETE $+\beta_{8}$ INSTIDEV $+\varepsilon$ Equation 3

The difference between equation 2 and equation 3 is that the latter does not distinguish between local and foreign firms. As such equation 3 examines both the direct and indirect effects of MNEs on the overall labour productivity in the UAE. From an economic viewpoint this manner of estimating technology transfer is more complete as it includes improvement in labour productivity that takes place within the MNE and may translate into a transfer at a later point in time. From a practical viewpoint we are forced to estimate the total impact because the UAE does not collect detailed data relating to foreign-owned firms and industry.

\section{DESCRIPTION OF THE VARIABLES}

Based on the development of our hypotheses and estimation we provide a formal definition of the dependent and independent variables used in this research ${ }^{4}$.

${ }^{4}$ These definitions have been adapted from the World Bank Development Indicators publications. 
LP

\section{FDISTOCK Stock value of Foreign Direct Investment}

FDI is calculated as the purchase/investment of 10\% or more of the voting shares or voting power as the level of ownership necessary for a direct investment interest to exist. This is calculated as the position at the end of the beginning of the period + FDI flows + exchange rate changes + other adjustments (such as reclassifications etc.). These data are obtained from the United Nations Committee on Trade and Development.

\section{IMITATE Imitation}

Imitation invariably leads to new fixed investment; therefore, in this study we measure imitation as the increase or change in domestic capital formation. The source of the data is the World Bank World Development Indicators (2011).

\section{LABOUR Labour mobility}

At a practical level it is almost impossible to obtain the level of labour mobility data as it would involve tracking employees working in foreign owned companies (Saggi, 2002). As a result, prior literature tends to use various proxy measures for labour mobility, a common one being the level of secondary school education. The source of the data is the World Bank World Development Indicators (2011).

\section{OPEN Trade openness}

A country that has a high proportion of trade over GDP is considered to be far more open than one where the ratio is low. Trade is the sum of exports and imports of goods and services measured as a share of gross domestic product. The source of the data is the UAE Ministry of Foreign Trade.
Host country factors and technology transfer in UAE 
IJIKMMENA

3,1

15
ABSORB

ECDEV

COMPETE The degree of domestic competition

If imports are high then it is assumed that the level of domestic competition is low and vice versa. We calculate this measure for domestic competition as gross imports minus re-exports, which is then divided by domestic manufacturing output. The import and re-export data is obtained from the UAE Ministry of Foreign Trade, while the manufacturing output data is taken from the World Bank World Development Indicators (2011).

INSTIDEV The level of institutional development

The Heritage Foundation produces a definition of institutional development using 10 indicators which range from business to monetary freedom. In keeping with prior literature such as Meyer and Sinani (2008) we have used the Heritage Foundation Economic Freedom. We have used the overall measure that includes all ten aspects of institutional development including corruption. High values indicate high levels of institutional development and vice versa.

\section{DATA}

We carry out descriptive statistics of our data set in order to better understand their distribution. The output of our descriptive statistics is shown in Table 2 below. 


\begin{tabular}{lccccc}
\hline & $\mathrm{N}$ & Minimum & Maximum & Mean & Std. Deviation \\
\hline LP & 30 & $2.7965 \mathrm{E} 4$ & $9.2879 \mathrm{E} 4$ & $4.2571 \mathrm{E} 4$ & $1.6381 \mathrm{E} 4$ \\
FDISTOCK & 30 & 392.29 & 72226.53 & 10432.7124 & 20611.63298 \\
IMITATE & 29 & $-4.0435 \mathrm{E} 10$ & $7.4883 \mathrm{E} 9$ & $-2.5703 \mathrm{E} 8$ & $7.9802 \mathrm{E} 9$ \\
LABOUR & 28 & 48.3002 & 95.2003 & 71.4701 & 12.3709 \\
OPEN & 28 & $8.7134 \mathrm{E} 1$ & $1.65474 \mathrm{E} 2$ & $1.2541 \mathrm{E} 2$ & $2.50745 \mathrm{E} 1$ \\
ABSORB & 28 & $6.7107 \mathrm{E} 3$ & $1.4841 \mathrm{E} 4$ & $9.6493 \mathrm{E} 3$ & $2.5692 \mathrm{E} 3$ \\
ECDEV & 30 & $1.4172 \mathrm{E} 4$ & $5.8272 \mathrm{E} 4$ & $2.4051 \mathrm{E} 4$ & $1.1139 \mathrm{E} 4$ \\
COMPETE & 27 & $2.1221 \mathrm{E} 0$ & $5.0629 \mathrm{E} 0$ & $3.0438 \mathrm{E} 0$ & .8049 \\
INSTIDEV & 15 & 57.1 & 60.2 & 58.787 & 1.1544 \\
\hline
\end{tabular}

Host country factors and technology transfer in UAE

Table 2. Descriptive statistics for trade, $\mathrm{FDI}$ and technology transfer characteristics

In the case of the dependent variable, we find that over the thirty year period ending 2010, the mean value is AED 42, 571 with a standard deviation of 16,381 .

IMITATE which we proxy through the use of annual increase in domestic capital formation has a mean value that is negative. The main reason for this is that there are a number of years when annual increase in domestic capital formation fell. Typical examples include the period from 1980 to the mid-1980s, early 1990s and after the international financial crisis in 2008.

LABOUR represents the percentage of the population above the age of 15 who have completed secondary school education. At the start of the observation period about $50 \%$ of the population had completed secondary school education, a figure which had increased to $95 \%$ thirty years later.

Trade has been an important aspect of the UAE economy and therefore it is no surprise that the economy is extremely open. At the start of the observation period in 1980, trade represented 100\% of GDP. Over the thirty year period, this figure increased to $160 \%$ just before the international financial crisis, and then came down slightly. Throughout the observation period, trade has been greater than the value of GDP. In this study we use capital intensity to proxy for prior knowledge with the implication that a country with a higher level of capital intensity is more 
IJIKMMENA 3,1

able to absorb new technology. The data show that on average capital intensity was US $\$ 9,600$ during the observation period.

The GDP per capita has varied greatly over the last thirty years. Between 1980 and 1988, GDP per capita halved in the country. The huge reduction in GDP per capita during this period was the regional uncertainty as a result of the Gulf War. GDP per capita increased from the end of the Gulf war to the invasion of Kuwait, after which it fell, reaching a low point in 1994. As from the start of the millennium, GDP per capita has been increasing each year and in 2008 was US $\$ 58,000$ before falling to about US\$50,000 in 2010. The mean value over the thirty year observation period for GDP per capita has been US $\$ 24,000$.

The level of competition in the economy i.e. COMPETE is proxied through the import intensity. The level of import intensity in the economy has varied considerably reflecting the level of domestic production and the opportunities that firms have had within the region. Our data for institutional development are a comprehensive composite of ten factors compiled by the Heritage Foundation. According to the measure, higher values imply a higher level of institutional development. The mean value over the observation period has been 58.8 with a low value of 57.1 in 1996 and a high point of 60.2 in 2008. Consistent with most of the indicators discussed above, there appears to be a significant decline in institutional development during the 1990s. From the start of the current millennium, institutional development has increased each year. However, the improvements made in institutional development have been very small.

\section{RESULTS}

We find ECDEV to be statistically significant at the $1 \%$ level, implying that the level of economic development has a positive and important impact on the level of technology transfer from the MNE to domestic firms. As such we find that our result is consistent with much prior research which also found the level of host country economic development to be an important contributory factor to technology transfer. For instance, Romer (1993) found that capital was not the problem for developing countries, but rather their ability to apply the new information. This is relevant for the UAE, which is one of the top five producers of hydrocarbons in the world and has no external federal government debt of any kind. Our statistically significant and positive relationship 
between ECDEV and labour productivity also supports the findings of Blomström and Kokko (1998), Borensztein et al. (1998), de Mello (1999), Campos and Kinoshita (2002) and Tu and Tan (2012), which showed that inward FDI had a positive impact in the higher income developing countries and not in the lower incomes group.

We find that absorptive capacity of the UAE has had a positive impact on the level of technology transfer. Although, the results are consistent with prior literature including Borensztein et al. (1998), the level of statistical significance in our study is only $10 \%$. We feel that the lower statical significance is due to the fact that a large proportion of inward FDI into the UAE is into the hydrocarbon sector. This is a rather unique sector in that the operators of the hydrocarbon plants or rigs are an international consortia of MNEs. As such, these firms operate similar plants or rigs throughout the world and hence their own level of absorptive capacity, which is independent from the host country. In other words the unique nature of agreements that have been signed by the government in the hydrocarbon sector give operational control to consortia of MNEs who do not rely on the skills or knowledge available in the host country. However, the positive impact of ABSORB in our model does imply that outside the hydrocarbon sector, the level of absorptive capacity is an important factor in technology transfer from MNEs to domestic firms. Overall our result is consistent with prior literature (Blomström and Kokko, 1998).

Our results shows that COMPETE is positive and statistically significant at the $1 \%$ level. As such our results show that the level of competition brought about from the presence of MNEs encourages domestic firms to reassess their production processes and innovate in order to remain competitive. Our results are thus consistent with prior studies such as Blomström and Kokko (1998) and Glass and Saggi (2002). Taking the OLS results along with the correlation coefficients into consideration, we feel that COMPETE appears to be motivated by the need for survival, as opposed to the other two motivations listed by Aghion and Howitt (1998) and discussed in our hypotheses development section above. The reason for this is that COMPETE becomes relevant when the economic indicators are falling and the domestic market conditions are difficult. In some sense, this is similar to the findings of Nickell (1996) whereby financial pressures impacted on the domestic firms' acquisition of technology.

Prior literature has found that trade openness leads to greater technology transfer from the MNE to the domestic firms. The argument
Host country factors and technology transfer in UAE 
IJIKMMENA 3,1

is that domestic firms learn from foreign MNEs as well as developing strategies to deal with the increased level of competition. Therefore, trade openness is assumed to have a positive relationship with technology transfer (Aitken, Hanson and Harrison, 1997; Barrios, Görg and Strobl, 2003; Greenaway, Sousa and Wakelin, 2004). Our results do find a statistically significant relationship between labour productivity and trade openness (i.e. TRADE) at the $1 \%$ level. However, unlike the other studies, we find a negative relationship which begs the questions as to why greater trade openness leads to a lower level of technology transfer. We believe that to answer this question one has to examine the trade activity in the UAE. The most important segment is re-exports and as such, the UAE is the world's third largest re-export centre after Hong Kong and Singapore. The re-exporter thus adds little to the GDP of a country and even less as far as technology transfer is concerned. Therefore any improvement in trade openness tends to make a greater difference to the re-export sector. Second, the gold and jewellery exports constitute approximately $60 \%$ of the export value 5 . In the case of gold, the UAE imports scrap gold and refines it for export, while the jewellery items are produced using largely cheap expatriate labour. The gold and jewellery sector thus has limited levels of technology transfer in the country and any increase in exports does not change the production process. The very nature of gold refining implies that UAE companies are not exposed to new technology because similar processes are used in the developed countries. Third, the countries to which the UAE exports tend to be regional and the price is elastic in nature, whereby quality is of secondary importance. For instance, India accounts for about $40 \%$ of exports, followed by Iran, Saudi Arabia and Pakistan. In fact, about $80 \%$ of the country's non-oil exports are accounted for by ten regional countries. Our results lead us to believe the emphasis for UAE firms has been to lower price rather than acquire new technology when trade openness increases. However, when regional countries reduce their imports then UAE firms are more likely to acquire new technology in order to survive or target countries where quality is more important than price.

Our results show INSTIDEV to be statistical significant at the 5\% level, implying that it does impact the level of technology transfer. However, contrary to our expectations we find a negative relationship between INSTIDEV and labour productivity. We believe that any improvement in institutional development alters the balance of power from domestic firms to MNEs. In other words, domestic firms feel more

${ }^{5}$ Source: UAE Ministry of Foreign Trade data 
comfortable in an environment whereby social networks allow them to obtain the necessary permissions and permits, i.e. less developed institutional structures. In a more transparent system it appears that domestic firms become less likely to invest in new technology.

Our results show a statistically significant relationship between the proportion of labour with secondary level education and labour productivity at the $5 \%$ level. However, contrary to our expectations we find a negative relationship between labour productivity and LABOUR. We believe that the UAE is unique globally in that $90 \%$ of the population is foreign and expatriate in nature. As such we believe that the decision of MNEs to locate in the UAE is not determined by their ability to recruit from the local population but the ease to which they can employ from the wider region. We also believe that the fact that MNEs can employ foreign labour has a negative impact on the level of technology transfer that can take place in the country. The reason being that foreign labour is usually tied to the company through various factors such as the need to obtain "a letter of no objection" from the current employer before they can move to another firm, which is rarely provided, together with employment clauses that restrict their ability to join other firms in the same sector.

We do not find any statistically significant relationship for FDISTOCK and IMITATE with labour productivity. We feel that in the case of FDISTOCK, it is not the stock of inward investment that determines the level of technology transfer, but the sectors in which it takes place. We believe that certain sectors have a greater probability of leading to technology transfer, while other do not. The most important sector since 2002 has been the property and real estate sector. This particular sector is not characterised by a high level of technology, and particularly in the UAE, low paid workers from the region are used. This implies that for inward FDI to make a significant impact it needs to target key sectors with new technology that can be transferred to domestic firms and used across different sectors. Similarly, we do not find that UAE companies imitate foreign MNEs.

\section{POLICY IMPLICATIONS}

Our study finds very important results which necessitate a change in the country's FDI policy, and to some extent, its industrial structure. We find the ECDEV to be an important contributory factor to technology
Host country factors and technology transfer in

UAE 


\begin{tabular}{|c|c|c|c|c|c|c|c|}
\hline \multirow{3}{*}{$\begin{array}{l}\text { IJIKMMENA } \\
3,1\end{array}$} & & & & & & & \\
\hline & & & \multicolumn{2}{|c|}{$\begin{array}{l}\text { Unstandardized } \\
\text { Coefficients }\end{array}$} & $\begin{array}{l}\text { Standardized } \\
\text { Coefficients }\end{array}$ & \multirow[b]{2}{*}{$\mathrm{t}$} & \multirow[b]{2}{*}{ Sig. } \\
\hline & \multicolumn{2}{|r|}{ Model } & B & Std. Error & Beta & & \\
\hline \multirow{4}{*}{21} & LP & (Constant) & 40127.147 & 13348.657 & & 3.006 & .007 \\
\hline & & FDISTOCK & -.033 & .035 & -.041 & -.925 & .366 \\
\hline & & IMITATE & $3.669 \mathrm{E}-8$ & .000 & .018 & 1.275 & .216 \\
\hline & & LABOUR & -72.904 & 32.378 & $-.053^{b}$ & -2.252 & .035 \\
\hline \multirow{6}{*}{$\begin{array}{l}\text { Table 3. OLS } \\
\text { Estimates for } \\
\text { FDI, technology } \\
\text { transfer and labour } \\
\text { productivity model }\end{array}$} & & OPEN & -43.791 & 10.954 & $-.065^{\mathrm{a}}$ & -3.998 & .001 \\
\hline & & ABSORB & .205 & .115 & $.031^{\mathrm{c}}$ & 1.789 & .088 \\
\hline & & ECDEV & 1.590 & .073 & $1.081^{\mathrm{a}}$ & 21.793 & .000 \\
\hline & & COMPETE & 852.065 & 170.302 & $.040^{\mathrm{a}}$ & 5.003 & .000 \\
\hline & & INSTIDEV & -498.654 & 219.956 & $-.024^{b}$ & -2.267 & .034 \\
\hline & & rs to $1 \%$, & d $10 \%$ sign & hce levels & & & \\
\hline
\end{tabular}

transfer. We believe that the government needs to enhance the level of economic growth, which from our study tends to lead to a higher level of technology transfer. In addition to this we feel that the country needs to reassess its trade policy. There is considerable prior literature to support a positive relationship between an open trade environment and technology transfer. However, we do not find this relationship to exist in the case of the UAE, because we believe that trade is heavily biased towards the re-export sector as well as in low technology sectors such as gold and jewellery. We do not argue for a trade policy that disadvantages these sectors because they are important for the country's non-oil economy. Instead we believe that the country needs to implement a trade policy that seeks to develop new sectors that are capable of being globally competitive. In doing so, the country should seek to place a lower emphasis on re-exports and the gold and jewellery sector. More importantly, the new sectors should be capable of absorbing new technology and transferring it to different industries within the country.

Overall, the evidence seems to suggest that in general, intervention should be targeted largely at providing a supportive economic environment. More specifically, this flags up a role for the effective use of Trade Related Investment Measures (TRIMs). The TRIM Agreement is part of the World Trade Organisation treaties and allows countries to impose certain restrictions. In the past countries have imposed some of the following restrictions on inward FDI: use of locally produced 
goods; domestic manufacturing of certain components; trade balancing; domestic sales; technology transfer requirements, export of a specified percentage of production volume; local ownership rules; foreign exchange and remittance restrictions; licensing and employment restrictions. Although some of these measures, such as use of locally produced goods are now banned, we nevertheless believe that the government needs to develop measures which are permitted by the WTO and assist local firms in acquiring technology from MNEs. For instance, we believe that the government can play a facilitating role to create effective and tangible linkages between MNEs and domestic firms, especially SMEs. We believe that the development of linkages will lead to the flows of technology transfer. This is an important issue where MNEs are located in free zones and do not have any contact with local firms who are outside free zones. We also believe that part of the incentives provided to MNEs should require them to mentor and work with local firms so that a flow of knowledge can take place and stimulate inter-industry spillovers.

We do not find evidence to support the assertion that labour mobility takes place from MNEs to domestic firms; hence the flow of knowledge from the former to the latter does not take place. We believe that the heart of this problem is the structure of the local labour force and the educational system in the country. In the case of the latter, we find that from a listing of all accredited universities by the UAE Ministry of Higher Education and Research, only a handful offer courses in subjects other than Business Studies and Information Technology ${ }^{6}$. We find that such a narrow and highly concentrated educational focus is not conducive to the acquisition of technology, especially scientific or production-based. Therefore, we believe that the government has to reassess its educational system and structure so that the foundation of technology is part of the school curriculum. In other words there needs to be an emphasis on developing a nation of people who have skills that are broader than business studies and IT. Similarly, universities have to be encouraged to offer a broad range of courses as a part of their accreditation and licence.

We believe that the highly concentrated nature of skills among the UAE nationals creates the first problem, namely the structure of the labour force. Data from the National Bureau of Statistics shows that about $40 \%$ of the UAE labour force is employed in government departments. As such, this segment of the labour force has little opportunity to benefit

${ }^{6}$ See the UAE Ministry of Higher Education and Scientific Research website for a listing of all accredited universities and courses.
Host country factors and technology transfer in UAE 
IJIKMMENA 3,1

from the knowledge flows from MNEs. More importantly, the UAE labour force that is employed in the private sectors tends to be in sectors where there are quotas and requirements, such as the oil and gas as well as banking sectors. We believe that UAE national labour needs to be re-skilled and retrained so that they can take a more effective role in the private sector. At the same time we believe that incentives need to be provided to UAE nationals to enter the private sector as well as to firms to recruit them. However, we appreciate that this will not happen unless the benefits in the government sector are brought down to levels where they are comparable to the private sector.

We believe that the government needs to have a well thought out inward FDI strategy that seeks to meet the objectives of its industrial and labour policies. In particular, we believe that the government needs to attract inward FDI that stimulates domestic firms in terms of startups, supply chains and acquisition of technology. We believe that the recent emphasis on property and real estate sectors has not had any impact on the flow of knowledge to domestic firms. We believe that in addition to selecting sectors that can assist the domestic industrial sector, inward FDI needs to be encouraged to actually conduct the bulk of their manufacturing in the country. In recent years there has been a flux of inward FDI but largely for the set up representative or sales offices with little in the way of actual production. Also, this inward investment needs to be encouraged to conduct $R \& D$ within the country. The actual process of $R \& D$ tends to spur two important spillover effects. First, the setting up of $R \& D$ in the country encourages domestic firms to establish similar facilities and develop technology. Second, R\&D creates linkages with universities through joint projects or even natural interaction among researchers. This encourages universities to conduct more applied research with market- based outcomes. In addition, the registering of patents in the country has a positive impact on the protection of knowledge as well as encouraging an innovation based culture in the country.

\section{CONCLUSIONS}

This study has examined the very important issue of host country factors and their impact on the level and speed of technology transfer from MNEs to domestic firms. Prior literature has found that there are three key transmission mechanisms by which MNEs can transfer knowledge to domestic firms, namely through imitation, labour mobility and trade openness. 
Our results show that the level of economic development positively impacts on labour productivity. As such we find evidence which leads us to support prior studies such as Blomström and Kokko (1998), Borensztein et al. (1998), de Mello (1999), Campos and Kinoshita (2002) and Tu and Tan (2012) which showed that inward FDI had a positive impact in the higher income developing countries and not in the lower incomes group. We find evidence that absorptive capacity has a positive impact on the level and speed of technology transfer from the MNE to domestic firms.

In the absence of competition, domestic firms lack incentive and will be content to use older technology. Our results thus show that the level of competition brought about from the presence of MNEs encourages domestic firms to reassess their production processes and innovate in order to remain competitive. Our results are thus consistent with prior studies such as Blomström and Kokko, (1998) and Glass and Saggi (2002). Taking the OLS results along with the correlation coefficients, we feel that COMPETE appears to be motivated by the need for survival.

We find a negative result for trade openness, contrary to our expectations, and we believe this is due to the importance of the reexport sector in the economy. In addition, the high weight of gold and jewellery exports along with a heavy focus on regional and elastic markets limit the ability of technology transfer to take place. We believe that any improvement in institutional development alters the balance of power from domestic firms to MNEs. In other words, domestic firms feel more comfortable in an environment whereby social networks allow them to obtain the necessary permissions and permits, i.e. less developed institutional structures. In a more transparent system it appears that domestic firms become less likely to invest in new technology.

Our results show a statistically significant relationship between the proportion of labour with secondary level education and labour productivity. However, contrary to our expectations, we find a negative relationship between labour productivity and LABOUR. We believe that the UAE is unique globally in that $90 \%$ of the population is foreign and expatriate in nature. As such we believe that the decision of MNEs to locate in the UAE is not determined by their ability to recruit from the local population, but the ease to which they can employ from the wider region. We do not find any
Host country factors and technology transfer in UAE 
IJIKMMENA 3,1 statistically significant relationship for FDISTOCK and IMITATE with labour productivity. We feel that in the case of FDISTOCK it is not the stock of inward investment that determines the level of technology transfer but the sectors in which it takes place. We believe that certain sectors have a greater probability of leading to technology transfer while others do not.

\section{REFERENCES}

Aitken, B., Hanson, G. and Harrison, A., (1997), "Spillovers, Foreign Investment, and Export Behavior", Journal of International Economics Vol. 43 No. 1, pp. 103-132.

Aitken, B.J. and Harrison, A.E. (1999), "Do domestic firms benefit from direct foreign investment? Evidence from Venezuela", The American Economic Review, Vol. 89 No. 3, pp. 605-618.

Aghion, P. and Howitt, P. (1998), Endogenous Growth Theory, MIT Press, Cambridge, MA.

Anderson, R.W. et al. (1996), Banking Sector Development in Central and Eastern Europe, London: CEPR and Institute for East-West Studies.

Bhagwati, J. (1994), "Free Trade: Old and New Challenges", Economic Journal, Vol. 104 No. 423, pp. 231-246.

Barrios, S. and Strobl, E. (2002), "Foreign Direct Investment and Productivity Spillovers: Evidence from the Spanish Experience", Weltwirtschaftliches Archive, Vol. 138, pp. 459-481.

Barrios, S., Holger, G. and Strobl, E. (2003), "Explaining Firms' Export Behaviour: R\&D, Spillovers and the Destination Market", Oxford Bulletin of Economics and Statistics, Vol. 65, pp. 475-496.

Barrios, S., Dimelis, S., Louri, H. and Strobl, E. (2004), "Efficiency spillovers from foreign direct investment in the EU periphery: A comparative study of Greece, Ireland and Spain", Review of World Economics, Vol. 140, pp. 687-705.

Blomström, M. and A. Kokko (1998), "Multinational Corporations and Spillovers", Journal of Economic Surveys, Vol. 12, pp. 247-248.

Borensztein, E., de Gregorio, J. and J-W. Lee. (1998), "How does foreign direct investment affect economic growth?" Journal of International Economics, Vol. 45, pp. 115-135. 
Campos N.F. and Kinoshita, Y. (2002), "FDI as Technology Transferred: Some Panel Evidence from Transition Economies", The Manchester School, Vol. 70 No. 3, pp. 398-419.

Carcovic M. and Levine R., (2002), "Does Foreign Direct Investment Accelerate Economic Growth?" Department of Business Finance, University of Minnesota, Working paper Series. Paper also available at: www.worldbank.org/research/conferences/financial globalization/fdi.pdf

Carr, D.L., Markusen, J.R. and Maskus, K.E. (2001), "Estimating the knowledge-capital model of the multinational enterprise", The American Economic Review, Vol. 91 No. 3, pp. 693-708.

Casado, M. (2000), "Human Capital in the Competitive Strategy of Multinational Companies in Spain," Documentos de Trabajo, Economics Faculty, UCM.

Cobb, C.W. and Douglas, P.H. (1928), "A Theory of Production", The American Economic Review, Vol. 18 No. 1, pp. 139-165.

Cohen, W.M. and Levinthal, D.A. (1989), "Innovation and Learning: The Two Faces of R\&D”, The Economic Journal, Vol. 99, pp. 569-596.

Cohen, W.M. and Levinthal D.A. (1990), "Absorptive Capacity: A New Perspective on Learning and Innovation", Administrative Science Quarterly, Vol. 35, pp. 128-152.

Cohen, W.M. and Levinthal, D.A. (1994), "Fortune Favors the Prepared Firm”, Management Science, Vol. 40, pp. 227-251.

Das, S. (1987), "Externalities and Technology Transfer through Multinational Corporations: A Theoretical Analysis", Journal of International Economics, Vol. 22, pp. 171-182.

de Gregorio, J. (2003), "The role of foreign direct investment and natural resources in economic development", Central Bank of Chile Working Papers, No. 196, Santiago.

de Mello, L. (1999), "Foreign Direct Investment-Led Growth: Evidence from Time Series and Panel Data", Oxford Economic Papers, Vol. 51, pp. 133-151.

Disney, R., Heden, Y. and Haskel, J.E. (2003), "Entry, Exit, and Establishment Survival in U.K. Manufacturing", Journal of Industrial Economics, Vol. L1, pp. 0022-1821.
Host country factors and technology transfer in UAE

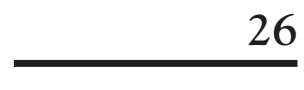


IJIKMMENA Dowell, G., Hart, S. and Yeung, B. (2000), "Do corporate global 3,1 environmental standards create or destroy market value?" Management Science, Vol. 46 No. 8, pp. 1059-1074.

Egger, P. and Pfaffermary, M. (2001), "A note on labour productivity and foreign inward direct investment", Applied Economics Letters, Vol. 8, pp. 229-232.

Enderwick, P. (1985), Multinational Business and Labour, London: Croon Helm.

Enkel, E. and Gassmann, O. (2010), "Creative imitation: exploring the case of cross-industry innovation", RED Management, Vol. 40, No. 3, pp.256-270.

Findlay, R. (1978), "Relative backwardness, direct foreign investment and the transfer of technology: a simple dynamic model", Quarterly Journal of Economics, Vol. 92, pp. 1-16.

Girma, S. and Wakelin, K. (2001), "Regional underdevelopment: Is FDI the solution? A semiparametric analysis", C.E.P.R. Discussion Paper no. 2995, Centre for Economic Policy Research, London, UK.

Glass, A. and Saggi, K. (2002), "Multinational Firms and Technology Transfer", Scandinavian Journal of Economics, Vol. 104, pp. 495-514.

Görg, H. and Greenaway, D. (2001), "Foreign Direct Investment and Intra-industry Spillovers: A Review of the Literature," Globalisation and Labour Markets Programme, Research Paper No. 2001/37, Leverhulme Centre for Research on Globalisation and Economic Policy, Nottingham, UK.

Görg, H. and Strobl, E. (2002), "Multinational companies and indigenous development: An empirical analysis", European Economic Review, Vol. 46, pp. 1305-1322.

Greenaway, D. Sousa, N. and Wakelin, K. (2004), "Do Indigenous Firms Learn to Export from Multinationals?" European Journal of Political Economy, Vol, 20 No. 4, pp. 1027-1043.

Griffith, R. (1999), "Using the ARD Establishment Level Data to Look at Foreign Ownership and Productivity in the UK", Economic Journal, Vol. 109, June, pp. F416-F442.

Grosfeld, I. and Tressel, T. (2001), "Competition, Corporate Governance: Substitutes or Complements? Evidence from the Warsaw Stock Exchange", CEPR Working Paper DP2888. 
Head, K. (1998), "Comment on Comparing Wages, Skills, and Productivity between Domestically and Foreign-Owned Manufacturing Establishments in the United States", in Baldwin, R., Lipsey, R. and Richardson, J.D. (eds.), Geography and Ownership as Bases for Economic Accounting, Chicago University Press, pp. 255-258.

Head, K., Ries, J.C. and Swenson, D.L. (2000), “Attracting Foreign Manufacturing: Investment Promotion and Agglomeration”, Regional Science and Urban Economics, Vol. 29, pp. 197-218.

Hermes, N. and Lensink, R. (2003), "Foreign Direct Investment, Financial Development and Economic Growth", Journal of Development Studies, Vol. 40 No. 1, pp. 142-163.

Kokko, A. (1994), "Technology, market characteristics and spillovers", Journal of Development Economics, Vol. 43 No. 2, pp. 279-293.

Kokko, A. and Blomström, M. (1995), "Policies to encourage inflows of technology through foreign multinationals", World Development, Vol. 23 No. 3, pp. 459-468.

Lane, P.J. and Lubatkin, M. (1998), "Relative absorptive capacity and interorganizational learning", Strategic Management Journal, Vol. 19 No. 5, pp. 461-477.

Larrain, F.B., Lopez-Calva, L.F. and Rodriguez-Clare, A. (2000), "Intel: A Case Study of Foreign Direct Investment in Central America”, Center for International Development Working Paper no. 58, Harvard University.

Lipsey, R. and Sjöholm, F. (2005), "The Impact of Inward FDI on Host Countries: Why such different answers?" in: Blomström, M., Moran, T.H., and Graham, E.M. eds. Does foreign direct investment promote development? Peterson Institute, pp. 23-45.

Makki, S. and Somwaru, A. (2004), "Impact of Foreign Direct Investment and Trade on Economic Growth: Evidence from Developing Countries," American Journal of Agricultural Economics, Vol. 86, pp. 795-801.

Mansfield, E. and Romeo, A. (1980), "Technology Transfer to Overseas Subsidiaries by U.S. Based Firms", Quarterly Journal of Economics, Vol. 9, pp. pp. 737-749.

McMillan, C.H. (1993), "The Role of Foreign Direct Investment in the Transition from Planned to Market Economies", Transnational Corporations, Vol. 2, pp. 97-119.
Host country factors and technology transfer in

$\mathrm{UAE}$ 
IJIKMMENA 3,1
Moen, J. (2000), "Is Mobility of Technical Personnel a Source of R\&D Spillovers?" National Bureau of Economic Research Working Paper \#7834, August.

Nickell, S. (1996), "Competition and Corporate Performance", Journal of Political Economy, Vol. 104, August, pp. 724-746.

Nickell, S. Nicolitsas, D. and Dryden, N. (1997), "What makes firms perform well?" European Economic Review, Elsevier, Vol. 41 No. 3-5, pp. 783-796.

Noorbakhsh, F., Paloni, A. and Youssef, A. (2001), "Human Capital and FDI Inflows to Developing Countries", World Development, Vol. 29, No. 9, pp.1593-1610.

North, D.C. (1990), Institutions, Institutional Change and Economic Performance, Cambridge; New York: Cambridge University Press.

O'Connor, D. and Lunati, M. (1999), "Economic Opening and the Demand for Skills in Developing Countries: A Review of Theory and Evidence", OECD Development Center Technical Papers No. 149.

Rodríguez-Clare, A. (1996), "Multinationals, Linkages, and Economic Development", American Economic Review, Vol. 86, pp. 852-873.

Rodrik, D., Subramanian, A. and Trebbi, A. (2002), "Institutions Rule: The Primacy of Institutions over Geography and Integration in Economic Development”, NBER Working Paper 9305.

Romer, P.M. (1990), "Endogenous technological change", Journal of Political Economy, Vol. 98, pp. 71-102.

Romer, P. (1993), "Idea gaps and object gaps in economic development", Journal of Monetary Economics, Vol. 32 No. 3, pp. 543-573.

Ruane, F. and Ugur, A. (2005), "Foreign direct investment and productivity spillovers in Irish manufacturing industry: Evidence from plant level panel data", International Journal of the Economics of Business, Vol.12, pp. 53-66.

Saggi, K. (2002), "Trade, foreign direct investment, and international technology transfer: A survey", World Bank Research Observer, Vol. 17, pp. 191-235.

Sinani, E and Meyer, K.E. (2004), "Spillovers of technology transfer from FDI: The case of Estonia", Journal of Comparative Economics, Vol. 32 No. 3, pp. 1-22. 
Solow, R.M., (1956), "A contribution to the theory of economic growth", Quarterly Journal of Economics, Vol. 70, pp. 65-94.

Swan, T.W. (1956), "Economic growth and capital accumulation", Economic Record, Vol.32, pp. 334-361.

Song, J., Almeida P. and Wu, G. (2001), "Learning-by-Hiring: When is Mobility Useful?" Paper presented at Technological Innovation and Evolution conference, March 2001.

Tushman M.L. (1977), "Special boundary roles in the innovation process", Administrative Science Quarterly, Vol. 22, pp. 587-605.

Tushman, M. and Scanlan, T. (1981), "Boundary spanning individuals: Their role in information transfer and their antecedents", Academy of Management Journal, Vol. 24 No. 2, pp. 289-305.

UNCTAD. (2001), Capital flows and growth in Africa, UN, New York and Geneva.

Tu, Y. and X. Tan, (2012), "Technology spillovers of FDI in ASEAN sourcing from local and abroad", China Finance Review International, Vol. 2 Iss: 1, pp. 78-94.

Wang, J.Y. and Blomström, M. (1992), "Foreign investment and technology transfer: A simple model”, European Economic Review, Vol. 36 No. 1, pp. 137-155.

Waltz, U. (1997), "Innovation, foreign direct investment and growth", Economica, Vol. 64, pp. 63-79.

Yao, S. (2006), "On Economic growth, FDI and exports in China under economic reforms", Applied Economics, Vol. 38 No. 3, pp. 339-352.

Zahara, S. and George, G. (2002), "Absorptive Capacity: A Review, Reconceptualization, and Extension", Academy of Management Review, Vol. 27 No. 2, pp. 185-203.

Zarsky, L. (1999), "Havens, halos and spaghetti: Untangling the evidence about foreign direct investment and the environment", in: OECD, ed.: Foreign Direct Investment and the Environment, Paris: OECD.

\section{ABOUT THE AUTHORS}

Fahad Saif Harhara is an Advisor in Business Development at Tawazun Economic Council. Fahad is a PhD student at Brunel University with a thesis in FDI \& Technology transfer. He holds a Masters in Business
Host country factors and technology transfer in

UAE 
IJIKMMENA 3,1

Administration from the American University of Dubai, a Masters Diploma in Electricity Supply Management from Cambridge University, UK, and a Bachelor of Science in Electrical Engineering from Virginia Commonwealth University in the United States. Fahad worked for almost thirteen years in leading positions at prominent organizations both inside and outside the UAE including the Emirates Identity Authority, Abu Dhabi Distribution Company, Abu Dhabi Water \& Electricity Authority, Thuraya Satellite Telecommunications Company and Virginia Micro Electronic Center, based in Richmond, Virginia, US. Fahad can be contacted at Fahadsaif@aol.com

Dr Amer Al-Roubaie is currently the Dean of the College of Business and Finance, Ahlia University, Bahrain. He obtained his $\mathrm{PhD}$ in Economics from McGill University in Montreal, Canada. He taught economics in Canada, the United States, Malaysia and the Middle East. For several years, Dr Al-Roubaie worked as a Research Fellow at the International Institute of Islamic Thought and Civilization (ISTAC), Malaysia. Basically an economist, his experience includes international business, finance, globalization, knowledge-based development, Islamic banking and finance and energy. He has participated in several conferences and attended seminars in many different countries. His publications include books, research reports and many articles which have appeared in a number of international journals. He can be contacted at aalroubaie@ahlia.edu.bh

Dr Wafi Al-Karaghouli, BA Statistics (Baghdad), MPhil Statistics and Operations Research (London), PhD IS Failures (Brunel), Cert. TQM, Cert. PRINCE2, MBCS, MElite, MPROMS-G, MRESG, FINFOMS. Wafi has gained extensive experience with multinational companies and has twelve years industrial experience, of which one was a blue-chip, and nineteen years in Higher Education. A qualified practitioner in Total Quality Management (TQM) and in Project Management Methodology PRINCE2, the synergy between past industrial experience and academic interests enables him to attempt to "bridge the gap" between theory and practice. Hence, his research tends to take the form of participatory action research and has embraced topics such as information system failure in business, systems thinking, problem solving, evaluation methodologies, organisational learning (OL) and knowledge management (KM). His areas of interest and research revolve around information technology systems failures (ITS), requirements engineering, IS in organizations, especially in retail, project 
management, operations management, TQM, civil aviation, healthcare, Islamic banking and business quantitative methods. Prior to Brunel, Wafi was a Senior Lecturer in Quantitative Methods and Information Technology at the University of Westminster, Westminster Business School (WBS), Marylebone Campus. Wafi is the founder and chair of the Middle East and Sustainable Developments Focus (MESDF) Group. He is also a member of the Heathrow Sector Steering Group. Wafi has published extensively on the subject of information systems failure in the retail sector and has contributed to the developments of the Wyatts Dealer Board System at Reuters in London, a Knowledge Management System at Merrill Lynch HSBC, Implementation and Use of Blackberry at Sage Publishing Company, and SITE, a Training Programme for new recruits at CACI Limited in London. Wafi has also contributed to the development of BAA's fast-track check-in desks at Heathrow Airport and the Iris Recognition Immigration System (iris). He can be contacted at Wafi.Al-Karaghouli@brunel.ac.uk
Host country factors and technology transfer in UAE 